\title{
Reply: Undinge, Coffee Cup Lids, and Reinhabiting Spaces: Some Notes on a Register of a (Post-)Critical Philosophical Life
}

\author{
Stefan Ramaekers (KU Leuven)
}

\begin{abstract}
:
The analyses in this issue on post-critique strike me as doing a particular kind of work, which I discuss in terms of 'finding (post-)critique's exact space'. And the philosophers developing the analyses all seem to be engaged, each in their own way, in a practice which I will discuss in terms of 'reinhabiting a space of (post-)critique'. I will draw on Ludwig Wittgenstein and Stanley Cavell to develop a few reflections on this. ${ }^{1}$
\end{abstract}

Keywords:

Cavell, coffee, critique, language, Wittgenstein

If being asked to briefly recap what the analyses in this issue on post-critique have to say about critique, a partial account of it would include what I sensed to be the presentation of critique as an Unding. Wittgenstein uses the term in the context of his discussion of a typical philosopher's examination of language (of what language is, what words are, what propositions are, etc.). Here Wittgenstein engages with the philosopher's inclination, when "[trying] to grasp the essence of the thing" (Wittgenstein, 1953/2009, \#116), to speak "outside" language-games (see e.g., Cavell, 1979, p. 207). His suggestion is to investigate whether "the word [is] ever actually used in this way in the language in which it is at home", something also captured when he says, in the same paragraph: "What we do is to bring words back from their metaphysical to their everyday use" (Wittgenstein, $1953 / 2009$, \#116). This is not to somehow restore (if such a thing was ever needed) ordinary language, or everyday usage of language, to some position deemed lost, nor is it to oppose ordinary language to a philosophical use of language. ${ }^{2}$ For current purposes, it suffices to observe that Wittgenstein draws our attention to "our practice of using language" (McGinn, 1997, p. 14). Or, as he puts this himself: "We're talking about the spatial and temporal phenomenon of language, not about some non-spatial, atemporal non-entity." (Wittgenstein, 1953/2009, \#108) 'Non-entity' is suggested here as translation for 'Unding' in the German original, but that doesn't entirely do the work I think the original German text suggests. (Nor does Anscombe's 1953 translation as 'phantasm'.)

Rather, an Unding brings to mind the take-away coffee cup lid. (A distant memory today perhaps but bear with me.) To start with, it's a p $\mathrm{p}^{* * * * * * * * * * *}$ to fit on the cup. While you're trying to fit it on you invariably spill some coffee (unless you're very skilled). But you need that lid because otherwise you will spill even more coffee when walking to wherever you're going. (Again, going somewhere is not our current ordinary, but let's say you're walking to your office). But even with the lid on, you're spilling coffee; through that very tiny hole, because of the movement of walking, and because the cup is very full. So you try to take a sip, to empty the cup a bit. But this is impractical. You have never mastered drinking while walking. And that hole is actually too small. And now you have burned your tongue because the coffee is too hot. Because, clearly, there's no way you can cool down your coffee with that lid on. So you're stuck: you either drink it too hot, or take the lid off again (bearing in mind you are still walking to your office) to blow on the coffee to cool it down. But that would leave you needing to squeeze that lid back on, only it's worse because now you're standing in the middle of the street. (You would have thought that after being in academia for so long, I would have mastered the skills involved. Nope.)

Seriously, that lid? It is such an Unding.

Maybe this is a somewhat uncommon analogy - coffee cup lid and language - but I hope it does convey a sense of what kind of 'non-entity/Unding' Wittgenstein, I speculate, might have had in mind when using it as a description of a particular philosophical use of language. It's 'something', for sure, but it doesn't really do its work, or perhaps more accurately: you can't really work with it. 'Idling' is another famous description Wittgenstein uses: "The confusions which occupy us arise when language is, as it were, idling, not when it is doing work." (Wittgenstein, 1953/2009, \#132) Again, the German original conveys something, I find, not entailed in its translation as 'idling'. 'Idling' captures the sense of 'doing nothing', 'hanging about'. It also captures the 
sense of an engine running while being stationary. In German, Wittgenstein uses 'leerlaufen' ("[...] wenn die Sprache leerläuft, nicht wenn sie arbeitet." (Wittgenstein, 1953/2009, \#132)), which next to idling can also be translated as 'being unproductive', something which, I find, resonates better with his use of 'arbeiten'. It's not doing the work it's supposed to do.

The collection of challenging, and at times provocative, analyses of the relevant concepts at stake in what a postcritical educational philosophy, and by extension pedagogy, might (and might not) be, often seem to present 'critique' as such an Unding, or as in serious danger of becoming one. The accounts of 'critique' developed in this issue - of critique as being 'relentless' or being stuck in a perpetual 'paranoid search' for hidden causes and deeper layers, or revelling in "a heady mix of complexity, indeterminacy, ambivalence, difficulty and more" (Anker, 2020, p. 5) - suggest that, according to these scholars, critique has become (and here they are following Latour) 'unproductive'. It's no longer clear what its purpose is, its actual functionality. To return to the coffee cup lid: at first sight it looks clear what it's for, but at a closer look, when actually using it, it's not something you can really work with (anymore). It's not helping you to enjoy your coffee. So, the change these analyses suggest we need to make, then, is highly needed, I think, both as, indeed, an alternative to the negativity of critique per se, or critique in educational philosophy, and as an anti-dote to contemporary political currents and their willing subjects who self-righteously, in the name of some vague notion of justice, indulge in relentless critiques of whatever or whoever is not perceived as sensitive enough to 'otherness'. (Ironically, the totalizing tendencies of this critical struggle for justice are something its proponents seem to be completely oblivious of.)

What I would like to focus on now is that the change proposed through these analyses is one, I would like to suggest, of a specific kind. Here I draw on Stanley Cavell to help me articulate this. The work done by these analyses is a kind of philosophical work which strikes me as how Cavell describes a particular kind of doing philosophy, c.q. ordinary language philosophy. (I am not saying the contributors to the issue are such philosophers. I merely want to suggest that the register in which these analyses are written seem to show something of this philosophy's characteristic practice.) Here is what Cavell says:

[...] the philosopher who proceeds from ordinary language is concerned less to avenge sensational crimes against the intellect than to redress its civil wrongs; to steady any imbalance, the tiniest usurpation, in the mind. This inevitably requires reintroducing ideas which have become tyrannical (e.g., existence, obligation, certainty, identity, reality, truth, ...) into the specific contexts in which they function naturally. This is not a question of cutting big ideas down to size, but of giving them the exact space in which they can move without corrupting.

\section{(Cavell, 1976, p. 18)}

If anything, critique could be added to the list of ideas in this quotation. And the shift envisioned by Cavell, from tyranny and corruption to a place where ideas can thrive, breath again, have a life, is how the change discussed in the analyses in the issue can be understood - be this either by suggesting to reinterpret critique, e.g., as Anker has it, "refashion its architecture" (Anker, 2020, p. 5) (redesigning the coffee cup lid?), or by seemingly moving away from it (redesigning the cup itself?).

But it is crucial to be clear about the notion of 'exact space' here. What needs to be appreciated is that this 'exact space' is not somehow 'out there', as if given; as if the only thing we need to do is 'put' this or that word - critique - into a space from which we have, wrongfully, taken it. It is by no means as simple as "a return to good sense or common sense" (Laugier, 2013, p. 86), nor a matter of setting up philosophical language against ordinary uses of words (as if the latter offers the (final) solution to philosophical problems). ${ }^{3}$ Cavell's emphasis, as I understand him here, is on the fact that someone has to perform this shift. I leave open the question whether or not this requires a 'new' concept (post-critique, instead of critique; sometimes "different words are called for", Felski says $(2020$, p. 2)). But it is clear to me that Cavell suggests that it is a 'personal' matter, or maybe more accurately put, an 'autobiographical' matter (see Cavell, 1994), a matter of showing (or not) a willingness to take up the claims inherent by using this or that word ('existence', 'certainty', ... and, I am adding, 'critique').

So instead of putting words back into a space 'out there', the matter is much more one of "reinhabiting" that space (Cavell, 1989, p. 82). Reinhabiting a space implies a form of change, both to the space and the one reinhabiting it. (I take it some contributors to the issue might suggest this practice to be an inherently educational endeavour.) Cavell brings out this sense of change, or "transfiguration", as he puts it (Cavell, 1989, p. 43), when he draws our attention to the German original text of a passage from Wittgenstein I already quoted above, about 'leading words back'. In the German original text the relevant verb is zurückführen. ("Wir führen die Wörter von ihrer metaphysischen, wieder auf ihre alltägliche Verwendung zurück," Wittgenstein says (1953/2009, \#116)). Cavell writes:

It would a little better express my sense of Wittgenstein's practice if we translate the idea of bringing words back as leading them back, shepherding them; which suggests not only that we have to find them, to go where they have wandered, but that they will return only if we attract and command them, which will require listening to them. [...] the behavior of words is not something separate from our lives, those of us who are native to them, in mastery of them. The lives themselves have to return. (Cavell, 1989, p. 35)

The analyses in the issue can be understood as 'leading' 
critique 'back' in this way, as moving beyond the pervasiveness of critique - to the point where it threatens to become an Unding - to consider what is actually done in the practice of critique. This means head-on confronting the ways in which we are implicated in critique, or post-critique. Simply put: it is us, we who are using the words, who have to be willing to change our use of them, to reorient them, and thus also who we are and allow ourselves to be. This is captured beautifully by Felski, who found herself unrightfully cornered "as being anti-theory and anti-critique" whereas she "was not slaying a dragon but reckoning with an intimate life partner of forty years. The sheen is long gone; quirks you once found endearing now drive you up the wall; you've heard their stories a few too many times" (Felski, 2020, p. 3). The work the papers in this issue do, each in their own way (which is instructive in its own right), is to show that staking a claim on critique, or post-critique, means staking one's subjectivity. To pick up on Felski (2020), this could very well be called learning to relate to one's own inheritance.
This also implies having to learn to relate to 'affirmativeness', and to its emotional undertones (love? A pinch of hate, as Snir (2020) has it?). Reinhabiting the space and time in which ideas can thrive, do their work, also means relearning how to express 'affirmativeness'. In educational philosophy this doesn't seem to be the register we most excel in. But it will be crucial that this happens, that this avenue is explored. 'Post-critique', as much as 'critique', is in danger, perpetually, of becoming an Unding itself. For if words are "not something separate from our lives" (Cavell, 1989, p. 35), then it is clear that we are doing the corrupting (or not). If there is corruption, it is we who are allowing it to grow rife. That is only a real problem when we overlook that it is in fact $u s$ who are the ones using these words, hence allowing them to do a certain kind of work.

So - that coffee cup lid. Redesigning the lid is an option, as is redesigning the cup. I suppose that whatever route is taken, it will anyhow require that we handle it with prudence. Tactfully, judiciously. That is, assuming that enjoying our coffee is the reason we buy it.

\section{References}

Anker, E. S. (2020). Beyond ambiguity and ambivalence: Rethinking the tools of critique. On Education. Journal for Research and Debate, 3(9). https://doi.org/10.17899/on_ed.2020.9.7

Cavell, S. (1976). Must we mean what we say? A book of essays. Cambridge University Press. https://archive.org/details/mustwemeanwhatwe00cave

Cavell, S. (1979). The claim of reason: Wittgenstein, skepticism, morality, and tragedy. Oxford University Press.

Cavell, S. (1989). This new yet unapproachable America: Lectures after Emerson after Wittgenstein. Living Batch Press. https://archive.org/details/thisnewyetunappr00stan/

Cavell, S. (1994). A pitch of philosophy: Autobiographical exercises. Harvard University Press. https://archive.org/details/pitchofphilosoph0000cave

Felski, R. (2020). Resonance and education. On Education. Journal for Research and Debate, 3(9). https://doi.org/10.17899/on_ed.2020.9.2

Hodgson, N., \& Ramaekers, S. (2019). Philosophical presentations of raising children: The grammar of upbringing. Palgrave Macmillan. https://doi.org/10.1007/978-3-030-12540-0

Laugier, S. (2013). Why we need ordinary language philosophy (D. Ginsburg, Trans.). University of Chicago Press. https://doi.org/10.7208/chicago/9780226037554.001.0001

McGinn, M. (1997). Wittgenstein and the philosophical investigations. Routledge.

Snir, I. (2020). Philophobia: From post-critical to neo-critical pedagogy through art critique (and a pinch of hate). On Education. Journal for Research and Debate, 3(9). https://doi.org/10.17899/on_ed.2020.9.10

Wittgenstein, L. (2009). Philosophische Untersuchungen: Philosophical investigations (P. M. S. Hacker \& J. Schulte, Eds.; G. E. M. Anscombe, P. M. S. Hacker, \& J. Schulte, Trans.; Rev. 4th ed.). Wiley-Blackwell. (Original work published 1953)

\section{Recommended Citation}

Ramaekers, S. (2020). Undinge, coffee cup lids, and reinhabiting spaces: Some notes on a register of a (post-)critical philosophical life: Reply. On Education. Journal for Research and Debate, 3(9).

https://doi.org/10.17899/on_ed.2020.9.15 


\section{About the Author}

Stefan Ramaekers is professor at the Research Unit Education, Culture, and Society (Faculty of Psychology and Educational Sciences) KU Leuven, Belgium. His research is situated in the field of educational philosophy, at the intersection of the AngloSaxon and Continental philosophical traditions, and finds inspiration in the work of Friedrich Nietzsche, Ludwig Wittgenstein, Stanley Cavell, and Franco Berardi. His main focus is a critical investigation of the contemporary discourse of parenting/upbringing. His most recent publications include a co-authored book with Naomi Hodgson, 'Philosophical Presentations of Raising Children. The Grammar of Upbringing' (2019, Palgrave Macmillan) (https://ppw.kuleuven.be/ecs/english/team/Team/00004310).

\footnotetext{
${ }^{1}$ The title is inspired by one of the later works of Stanley Cavell, Cities of Words. Pedagogical Letters on a Register of the Moral Life (2005).

${ }^{2}$ I cannot develop this here. For a brief reflection on this, see Hodgson and Ramaekers (2019, p. 18).

${ }^{3}$ Ordinary language philosophy has sometimes, and incorrectly, been construed as such. But this is not the place to go into that. (See e.g., Laugier, 2013; and see Cavell, e.g., 1979).
} 